\title{
Revisiting Teacher Adoption Of Technology: Research Implications And Recommendations For Successful Full Technology Integration
}

\author{
Janet Buckenmeyer, Purdue University Calumet
}

\begin{abstract}
Most teachers are still failing to fully integrate technologies in their classrooms to improve student achievement. If certain conditions exist, however, they are more likely to accept and use appropriate technologies in significant instructional ways. Relevant professional development and continuous access to needed resources are two significant factors contributing to technology adoption. Other factors evolving from research as well as recommendations for integration are presented.
\end{abstract}

\section{INTRODUCTION}

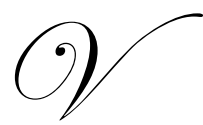

arious technologies have been introduced in schools over the last half-century. From phonographs and audiocassettes, to instructional television and distance learning, educational technologies have (or had) the potential to affect the practice of teachers and-more importantly-student achievement. Unmistakably, one of the most pervasive and far-reaching of the technological influences on teaching and learning has been the introduction of the computer and related technologies into the classroom (Office of Technology Assessment, 1995). While not a panacea to all of the problems and challenges that schools face (OTA, 1995), computer technology does provide teachers and students with abundant opportunities that were unavailable-or even possible--in previous generations. Computers offer many distinct advantages over other technologies including the capability of providing simulations of otherwise costly, time consuming, or dangerous situations. They also offer instant global communications and immediate access to limitless amounts of information.

Access to computers in classrooms is obviously the first step to integration. Overcoming common barriers, such as the lack of professional development, the lack of timely technical support, and a lack of consensus on the best instructional strategies (Kleiman, 2000) is equally important. When considering adoption issues, therefore, all essential conditions for appropriate technology integration need to be examined, not just the number of computers available. Thus, the challenge is not getting technology into classrooms, but instead, getting teachers and affiliated support systems prepared to use those technologies.

Despite extraordinary potential, school administrators and teachers in the United States still remain reluctant to universally embrace technological innovations for instructional purposes. Although access to technology within schools has expanded dramatically, evidence of policies designed to improve the ability of educators to use technology effectively is absent (Swanson, 2006).

\section{BARRIERS TO ADOPTION}

As early as 1999, a national survey by Becker (1999) revealed that a majority of teachers - as many as 70 percent - are not using technologies available to them. The reasons for this phenomenon are varied and complex. Some studies suggest that teachers' educational beliefs play an important role in how they choose and use 
technologies in their classrooms (Honey \& Moeller, 1990; Ertmer, 1999). The results of a more recent study by Firek (2003) remain disappointingly consistent with Becker's study: beginning teachers still lack the skills needed to successfully integrate technology into the curriculum.

Veteran teachers also experience obstacles. In 1993, Hadley and Sheingold concluded that access to technology was necessary but not sufficient for making appropriate integration possible. Marcinkiewicz (1994) concluded that simply having more technology does not in itself persuade teachers to begin or expand use. Several years later, the report entitled "Teachers' Tools for the $21^{\text {st }}$ Century: A Report on Teachers' Use of Technology," revealed that even now, though the majority of schools have access to some form of technology, a mere one-third of teachers report feeling well-prepared or very well prepared to use computers and the Internet for classroom instruction (National Center for Education Statistics, 2000).

Vast financial and human resources have been invested in technology integration to improve student achievement in schools. Results remain disheartening. In fact, reliable and measurable progress is absent, particularly over the past several years (Swanson, 2006).

Helping teachers use technology effectively may be the most important step to assuring that current and future investments in technology are realized (OTA, 1995). The question remains: what factors are related to appropriate incorporation of technology, and what conditions will foster adoption?

\section{CONDITIONS PROMOTING ADOPTION}

Technology integration does happen when teachers are prepared to use it (NCES, 2000; Becker, 1999). Relevant, continuous, and timely professional development must be offered. Small group and individual formats are the most effective. Self-paced, trial and error lessons are ideal for some individuals.

Second, adequate time must be allocated for teachers to learn new technologies and to integrate these technologies in their classrooms (Maney, 1999; Sandholtz, Ringstaff \& Dwyer, 1997; OTA, 1995; Hadley \& Sheingold, 1993; Franklin, Turner, Kariuki \& Duran 2002; Vannatta \& Fordham, 2004). Other researchers (Liu, Maddux, \& Johnson, 2004) correlated an essential seamless connection - time invested in learning and using technology has a positive relationship with technology achievement. When time provided is inadequate or limited, teachers often resort to what they already know. Their interest and enthusiasm in exploring new pedagogical approaches using technology will, therefore, wane. Time is an essential ingredient.

Third, quality and timely technical support must be offered (Maney 1999; McKenzie, 1999). Equipment malfunctions and unanswered questions lead to frustration and stress. Purposeful, results-oriented assistance delivering prompt resolutions reassures integration pioneers.

Finally, teachers' attitude toward technology is a consistently strong predictor of acceptance, adoption and use of technology (Marcinkiewicz, 1994; Honey \& Moeller, 1990; Craig, 2006; McGrail, 2005). Given this conclusion, Ertmer (2005) suggests that in order to affect teacher beliefs, research needs to be conducted where teachers have first-hand experiences with technology, where teachers observe successful implementation, and where change occurs through professional learning communities. In the meantime, capitalizing on technology integration advocates is highly recommended. These believers will catapult positive momentum.

\section{CONCLUSION}

If change is to occur in classrooms, it must begin with the teacher, not the technology. This work examined and presented the factors essential to teachers' adoption of full technology integration to improve student achievement. 


\section{AUTHOR INFORMATION}

Janet Buckenmeyer, Ph.D. is an Assistant Professor and Program Chair of the Instructional Technology Program for the Graduate School of Education at Purdue University Calumet. She teaches courses in appropriate technology integration, learning theories and technology, instructional design, and web-based instruction. Her research interests focus on technology integration and student learning, teacher preparation, and educational change.Dr. Buckenmeyer received her PhD in Curriculum and Instruction from the University of Toledo in 2001.

Contact Information: Purdue University Calumet, 2200 169th St., School of Education, Hammond, IN 46323; Email: buckenme@ calumet.purdue.edu; Phone: (219) 989-2692.

\section{REFERENCES}

1. Becker, H. J. (1999). Internet use by teachers: Conditions of professional use and teacher-directed student use. Teaching, Learning and Computing: 1998 National Survey, Report \#1. [online] 31 pages. Available: http://www.crito.uci.edu/TLC.findings/Internet-use/startpage.htm

2. Craig, D.J. (2006). Why is dissemination so difficult? The nature of teacher knowledge and the spread of curriculum reform. American Educational Research Journal, 43(2), 257-293.

3. Ertmer, P.A. (2005). Teacher pedagogical beliefs: The final frontier in our quest for technological integration? Educational Technology Research \& Development 53(4), 25-39.

4. $\quad$ Ertmer, P.A. (1999). Addressing first and second order barriers to change: Strategies for technology integration. Educational Technology Research \& Development 47(4), 47-61.

5. Firek, H. (April 2003). One order of ed tech coming up... You want fries with that? Phi Delta Kappan, 84, 596-597.

6. Hadley, M. \& Sheingold, K. (1993). Commonalities and distinctive patterns in teachers' integration of computers. American Journal of Education 101(3), 261-315.

7. Honey, M. \& Moeller, B. (1990). Teachers' beliefs and technology integration: Different understandings. Technical Report Issue No. 6. Washington, D.C.: Office of Educational Research and Improvement.

8. Kleiman, G. M. (2000, April-June). Myths and realities about technology in K-12 schools. LNT Perspectives: The Online Journal of the Leadership and the New Technologies Community, 14. [online] 9 pages. Available; http://www.edc.org/LNT/news/Issue14/feature1.htm

9. Liu, L., Maddux, C. \& Johnson, L. (2004). Computer attitude and achievement: Is time an intermediate variable? Journal of Technology and Teacher Education 12(4), 593-607.

10. Maney, J. K. (1999). The role of technology in education: Reality, pitfalls, and potential. In G. J. Cizek (Ed.), Handbook of educational policy (pp. 387-415). San Diego, CA: Academic.

11. Marcinkiewicz, H. R. (1994). Computers and teachers: Factors influencing computer use in the classroom. Journal of Research on Computing in Education, 26(2), 220-237.

12. McGrail, E. (2005). Teachers, technology and change: English teachers' perspectives. Journal of Technology and Teacher Education 13(1), 5-24.

13. McKenzie, J. (1998). Secrets of success: Professional development that works. eSchool News [online] 11 pages. Available:http://www.fromnowon.org/eschool/secrets.html

14. Sandholtz, J. H., Rinstaff, C, \& Dwyer, D. C. (1997). Teaching with technology: Creating student-centered classrooms. New York: Teachers College Press.

15. Swanson, C.B. (2006). Tracking U.S. trends. The Information Edge: Using Data to Accelerate Achievement, 25(35), 50-53.

16. U.S. Congress, Office of Technology Assessment. (1995). Teachers and technology: Making the connection. Washington, DC: U.S. Government Printing Office.

17. U.S. Department of Education, National Center for Education Statistics. (2000). Teachers' tools for the $21^{\text {st }}$ century: A report on teachers' use of technology. Washington, DC: U.S. Government Printing Office.

18. Vannatta, R. A., \& Fordham, N. (2004). Teacher dispositions as predictors of classroom technology use. Journal of Research on Technology in Education 36(3), 253-271. 
NOTES 